\title{
Raids made out by the Lushai Tribes in the Tea Gardens of Cachar during the Colonial Period: A Study on the Historical Perspective.
}

\author{
Dhriti Kanta Rajkumar ${ }^{1}$ \\ (Research Scholar, Department of History, Assam University)
}

\begin{abstract}
In this paper, an attempt has been made to discuss the impact of the large scale expansion of tea cultivation started by the European Entrepreneurs during the colonial period in Cachar, which affected the neighboring tribes, especially like the Kukis and Lushais, their social and economic conditions. This resulted in the constant raids of the neighboring tribes on the tea gardens of plains area of Cachar Valley. The nature of their raiding was burning villages, kidnapping and killing people. The name of the tea gardens of Cachar that the tribes were attacked, were - Rupcherra (1849), Adampore (1862), Chandraipur (1863), Loharbond (1868), Monierkhal (1869), Ainakhal (1871), Alexandrapur (1871), Katlicherra (1871), Dharmikhal (1871), Nagdirgram (1871), Jhallancherra (1871), Baruncherra (1892) and Baladan Tea Estate (1893). These raids executed by the Lushais ultimately led to the British Government to take severe measures with regards to them which ultimately brought the Lushai tribes under British regime on $27^{\text {th }}$ January, 1898.
\end{abstract}

Keywords: Entrepreneurs, Kukis, Lushais, raids, tea cultivation.

\section{Introduction}

\subsection{Historical Background Of The Establishment Of Tea Industry In Cachar}

It was mainly the commercial interest of the English East India Company that induced the British to establish the tea plantation in the Assam Valley including present Cachar during the early part of the $19^{\text {th }}$ century. The plantation grew incredibly during the last quarter of the $19^{\text {th }}$ century with the introduction of government's easy leases. This development ultimately led to the encroachment of the land belonging to the wild tribes, which seriously affected their economy and livelihood. Finally it disturbed the bordering between settled British territory and the territories of independent tribes, leading to conflict. Hence, the objective of this paper is to analyse how the tribes and their socio-economic conditions were affected by expansionary policy maintained by the European Entrepreneurs.

It is a generally accepted view that, China is the indispensable home of tea. Tradition ascribes the discovery of the tea bush to the Emperor Shin Nong also known as Yen Di or Shin Nong Shi (2852-2737 B C), the second of the three Chinese Emperors of the San Huang period (3000-2700 B C), three thousand years before the Christian era. ${ }^{1}$ The first book, 'Ch'a Ching' or 'Tea Classic' exclusively on tea was published in 780 $\mathrm{AD}$ by $\mathrm{Lu} \mathrm{Yu}$ in three volumes. It is divided into ten parts, each describing various kinds of tea, cultivation and manufacturing methods, etc. It gives information on the tea growing districts of China, claims that, tea originated in China. ${ }^{2}$ Due to the expansion of colonialism, soon tea was consumed throughout the world and accordingly, plantation of tea was taken up in various Asian and European countries like - Japan, Holland, Portugal, America and England. Finally, it extended to British India. In British India, the importance of starting tea industry was felt after the Charter Act of 1833, when the English East India Company's highly profitable trade on tea ended with China. ${ }^{3}$

The British East India Company took pioneering role in the development of tea trade and also in the tea plantation in India. The Company had the monopoly on tea and used to buy tea and silk from China in exchange of silver and bullion. The trade agreement of 20 years between China and Britain was over in 1833 and the Chinese government was reluctant to continue the trade agreement. ${ }^{4}$ In this connection, it is to be mentioned here that, suspecting such possibility, Sir Joseph Bank had suggested as early as 1788 the possibility of developing tea plantation in India so that in event of trouble with Chinese authority, an alternative source of

\footnotetext{
${ }^{1}$ Griffith, P, The History of the Indian Tea Industry, Weldenfield and Nicolson, London, 1967, p.4.

${ }^{2}$ Baruah, Pradip, The Tea Industry of Assam: Origin and Development, EBH Publishers, Guwahati, 2008, p.23.

${ }^{3}$ Awasthi, R C, Economics of Tea Industry in India, United Publishers, Guwahati, Assam, 1975, p.33.

${ }^{4}$ Sen, Benoy B, Origin and Development of Tea, EBH Publishers (India), Guwahati, 2008, P.8
} 
supply could be maintained. However, nothing came out from this proposal due to the fact that the Company's monopoly in tea trade earning huge profit would be affected. Hence, Bank's proposal was not entertained. ${ }^{5}$

The Act of 1833, thus, ended the most lucrative tea trade with China. This had a far-reaching consequence, because it became essential for the Company to find an alternative source of supply of tea under its exclusive control. This inspired Lord William Bentinck, the then Governor-General of India, to propose before the Council the formation of the 'Tea Committee' to investigate the possibilities of growing tea in India. Accordingly, on $1^{\text {st }}$ February 1834, the proposed 'Tea Committee' was formed, comprising of 11 Englishman and 2 Indians; they were - James Patel(Chairman), J W Grant, R B Mangles, J R Colvin, C E Trevelyan, C K Robinson, Robert Wilkinson, Sir Robert Colquhonn, Dr. N Wallich, Radhakanta Dev, Ram Kamal Sen and G J Gordon(Secretary). ${ }^{6}$ The appointment of the Committee in early 1834 contributed much to the development and expansion of the tea industry in India. The Committee undertook rapid surveys in various regions of the country to select a favourable site for planting tea bushes. With great labour, the committee succeeded to establish tea plantation in upper part of Assam in 1837 and this success led to a rapid stride in the path of introducing tea in colonial Cachar.

It is generally viewed that the discovery of indigenous tea in Assam is considered to be the starting of tea plantation in India. The credit for the discovery of tea in Assam in 1837 goes to Robert Bruce and his brother Charles Alexander Bruce, employee of the English East India Company. ${ }^{7}$ The 'Scientific Commission' constituted under the 'Tea Committee' in 1835 comprising of the members - Dr. N Wallich(Asst. Surgeon), Dr. J M Clelland(Geologist) and W Griffith(Botanist) was sent to Assam to survey and report on the Indigenous tea grown in Assam and to advise on the most favourable site for starting experimental tea gardens. ${ }^{8}$ The 'Scientific Commission' accordingly visited Assam in 1836 and finally it was able to recognize the indigenous tea plant in Assam, and it was also asserted that the tea plants found in this region were similar to that of the tea plants of China, scientifically known as 'camellia sinensis'.'

The success of the Company in their attempt to develop tea plantation in Upper Assam encouraged the British to expand the plantation in other parts of Assam including colonial Cachar. Though the indigenous tea plant in Cachar was first discovered in 1855, the speculation regarding the possibility of existence of indigenous tea trees had begun since its annexation in $1832 .{ }^{10}$ In February 1834, immediately after the appointment of the 'Tea Committee', G T Gordon, Secretary of the 'Tea Committee' requested Captain Fisher, Superintendent of Cachar, to gather information regarding the condition of soil, rainfall, climate etc. required for the cultivation of tea from the Chinese tea merchants coming to Cachar from the province of Yunan in China and to report if Cachar fulfilled such conditions. ${ }^{11}$

Accordingly, Fisher submitted a report to G Gordon, where he dealt with every point as regards soil, climate, rainfall etc. and concluded with his opinion that Cachar would be suitable for the plantation of tea. ${ }^{12}$ After this report, nothing happened immediately; but, it appears from the letter written by R Stewart, the then Superintendent of Cachar that, an employee of tea plantation of Assam had presented a Cachar tea plant to Stewart and told him that the plants were abundantly growing in the jungles of the district. ${ }^{13}$ Immediately after this, R Stewart submitted the specimen of the plant to Dr. Thomas, Superintendent of the Government Botanical Garden at Calcutta for confirmation, who recognized them as genuine tea plants. ${ }^{14}$

When R Stewart was convinced that the plant discovered was the genuine tea plant, he sent people in different directions into the jungles to look for it and wherever they went, the plant was found more or less in abundance. It is evident from a letter that, tea plants are found to the south and south-east of Silchar, the Sudder Station. ${ }^{15}$ The areas where tea plants were growing in abundance were the Bargoongoor Hills in the Chatla

\footnotetext{
${ }^{5}$ Kaushal, G, Economic History of India (1757-1966), Kalyani Publishers, N Delhi, 1991. p.234.

${ }^{6}$ Antrobus, H A, A History of the Assam Company (1830-1953), T and A Constable Ltd. Edinburgh, 1957, p.16.

${ }^{7}$ Griffith, P, The History of the Indian Tea Industry, Weldenfield and Nicolson London, 1967, p.36.

${ }^{8}$ Ibid, p.24.

${ }^{9}$ Baruah, Pradip, The Tea Industry of Assam: Origin and Development, EBH Publishers (India), 2008, p.1

${ }^{10}$ Dutta, D (Ed.), Purbasree, G C College Mgazine, 1965, p.99

${ }^{11}$ Bhattacharjee, J B, Cachar Under British Rule in North-East-India, Radiant, New Delhi, 1977, p.189

12 An early letter on the tea industry written by T Fisher, Esq., A A G G to G S Gordon, Secretary to the Committee for Tea Culture, dated, $25^{\text {th }}$ March 1834, District Record Room, Silchar.

13 A Government Letter from G Verner, Superintendent of Cachar, to W Grey, Esqr., Secretary to the Government of Bengal, Fort William, No. 180 of 1855, dated, $10^{\text {th }}$ July 1855, District Record Room, Silchar.

${ }^{14}$ Bhattacharjee, J B, Cachar Under British Rule in North-East-India, Radiant, New Delhi, 1977, p.189

${ }^{15}$ A Government Letter from G Verner, Superintendent of Cachar, to R Houston, Esqr., No. 211 of 1855, dated, $4^{\text {th }}$ September 1855, District Record Room, Silchar.
} 
Howher, Baokara and Nawowalla near the Gagra river, Barrahungun near Hailakandi and in the east of Rajnagar Parganah. From the same letter, it is also known that Barrahangun ( present Kathal Bagan) was the first place where the first tea plantation was started in 1855, by Williamson and Company.

Based on these findings, the 'Tea Committee' resolved to introduce tea plantation in Cachar. After the discovery, wide publicity was given with a view to inviting people to come to Cachar to undertake the work of tea cultivation and to receive grants of land from the Government in easy terms and conditions. In this connection, it is found from the letter that, G Williamson, the Superintendent of the Assam Tea Company, happened to be the first tea Planter, who was offered the first grant of 742 acres of land in Burrahangun for 99 years. ${ }^{16}$

Having considered the progress of tea plantation in Cachar, G Verner, the then Superintendent of Cachar, proposed the rules, known as the Old Assam Rules to be adopted, while undertaking the tea plantation in Cachar. ${ }^{17}$

In the subsequent period, in order to encourage the cultivation of tea, the Government created revenue free or concessional revenue paying estates by settling waste land with tea Planters in perpetuity. The Waste Land Settlement Rules were first framed in 1838 and later on modified successively especially during 1860 $1880 .^{18}$

\section{Application For Grants}

In response to the publicity made by the Government, a good number of Planters and entrepreneurs came forward to Cachar and started tea plantation. According to the report of the "Annual Administration of the district of Cachar 1871-1872', there were total 278 applications registered. ${ }^{19}$ Out of these 181 grants were finally made, amounting on rough survey to 484,760 acres. On the basis of availability of sources, the following entrepreneurs communicated with the Government in an earlier date from 1855 to have facilities for the establishment of tea plantation as per Government rule ${ }^{20}$ -

TABLE - 1Land Grants Applied by the Companies

\begin{tabular}{|l|l|l|}
\hline $\begin{array}{l}\text { Name of the Planters } \\
\text { and Company }\end{array}$ & Land Grants & Date and Year \\
\hline G Williamson \& Co. & 1000 acres (Burrahangun) & Dtd. $4^{\text {th }}$ Sept.1855 \\
\hline Cecil Huttman, Calcutta & 500 acres (NA) & Dtd. 25 $5^{\text {th }}$ Oct. 1855 \\
\hline George Cowan, Calcutta & 500 acres (NA) & Dtd. 25 $5^{\text {th }}$ Oct. 1855 \\
\hline Thomas Barry, Calcutta & (NA) & (NA) \\
\hline W Spink, Calcutta & 700 acres & Dtd. 20 $0^{\text {th }}$ Oct. 1855 \\
\hline Thomas Hewitt, Calcutta & 600 acres & Dtd. $5^{\text {th }}$ Nov. 1855 \\
\hline Mackintosh, Calcutta & (NA) & (NA) \\
\hline M Hering, Silchar & $500-700$ acres & $25^{\text {th }}$ Nov. 1855 \\
\hline Mr. Sweetian & (NA) & $8^{\text {th }}$ Dec. 1855 \\
\hline J B Barry & (NA) & $26^{\text {th }}$ Nov. 1855 \\
\hline Lt. Viacent & 1000 acres & $4^{\text {th }}$ Jan. 1856 \\
\hline L M L Cromartie & (Chundighat and Sheburbond Area) & (NA) \\
\hline Shadwell, Cherrapunjee & 1000 acres & $17^{\text {th }}$ Dec. 1855 \\
\hline Sgt. Fitzgerald, Cachar & 500 acres(Kunchunpoor Area) & $3^{\text {rd }}$ Feb. 1856 \\
\hline Sergeon C R Chalmers & 1000 acres & $5^{\text {th }}$ May 1856 \\
\hline A Tyod of Wise \& Co. & Boakara Grant & (NA) \\
\hline M Herring & (Kunchunpoor Area) & (NA) \\
\hline Charles Mackey & 500 acres & (NA) \\
\hline J Hogg & (Burkholla Area) & (NA) \\
\hline H G Touchy & (Kishunpoor Area) & (NA) \\
\hline J Abernethy & (Monacherra Area) & (NA) \\
\hline P Saunders & (Jalingah Area) & (NA) \\
\hline & & \\
\hline
\end{tabular}

${ }^{16}$ A Government Letter from R Stewart, Superintendent of Cachar, to the Commissioner of Revenue, Cherra, No. 65 of $1858,19^{\text {th }}$ April, 1858, District Record Room, Silchar.

${ }^{17}$ State Archives and Record Room, Guwahati

${ }^{18}$ File No- 103-199 BG State Archives and Record Room, Guwahati.

${ }^{19}$ State Archives and Record Room, Gauhati, File No. 636 AC, 1872.

${ }^{20}$ State Archives and Record Room, Guwahati and also District Record Room, Silchar 


\begin{tabular}{|l|l|l|}
\hline W Alfred & (Jaffirbund Area) & (NA) \\
\hline H G Gibson & (Mohunpoor Area) & (NA) \\
\hline \multicolumn{2}{|c|}{ NA = Not Available }
\end{tabular}

Beside the above applicants, it also appears that there were more 16 applicants who applied for the wasteland for starting tea plantation in Cachar. ${ }^{21}$ They were -

TABLE - 2 Application applied for the Wasteland by the Companies

\begin{tabular}{|c|c|c|c|}
\hline $\begin{array}{l}\text { Name } \\
\text { Applicant }\end{array}$ & Land where situated & $\begin{array}{l}\text { Area applied for } \\
\text { A R P }\end{array}$ & Date of application \\
\hline $\begin{array}{l}\text { W P Williamson, } \\
\text { Esq }\end{array}$ & $\begin{array}{l}\text { Pergunnah Roopairballi, } \\
\text { mouza Captainpur }\end{array}$ & 272033 & $24^{\text {th }}$ March 1870 \\
\hline H Haws, Esq & $\begin{array}{l}\text { Pergunnah Burkbela, mouza } \\
\text { Abong }\end{array}$ & 738323 & $9^{\text {th }}$ Feb. 1871 \\
\hline Mr. Milne & $\begin{array}{l}\text { Pergunnah Chatlakowar, } \\
\text { mouza Jallingah }\end{array}$ & 34332 & $20^{\text {th }}$ Feb. 1871 \\
\hline Ditto & Ditto & 61014 & Ditto \\
\hline $\begin{array}{l}\text { James Vavidson, } \\
\text { Esq }\end{array}$ & Pergunnah Kalline & 342230 & $4^{\text {th }}$ Apr. 1871 \\
\hline $\begin{array}{lrl}\text { Mr. } \quad \mathrm{W} & \mathrm{P} \\
\text { Williamson } & \end{array}$ & $\begin{array}{l}\text { Pergunnah } \\
\text { mouza Degur Telka }\end{array}$ & 538339 & $1^{\text {st }}$ July 1871 \\
\hline C J Brown, Esq & Pergunnah Woodharbund & 200000 & Ditto \\
\hline $\begin{array}{l}\text { Donald Steel, } \\
\text { Esq }\end{array}$ & Pergunnah Burkhola & 29717 & $22^{\text {nd }}$ Dec. 1871 \\
\hline J P Stuart, Esq & Pergunnah Woodharbund & 262618 & $29^{\text {th }}$ Jan. 1872 \\
\hline L Mosely, Esq & Pergunnah Baskandy & 5430 & $5^{\text {th }}$ Feb. 1872 \\
\hline W Aitchison, Esq & $\begin{array}{l}\text { Pergunnah Burkhola mouza } \\
\text { Abong }\end{array}$ & 1087120 & $9^{\text {th }}$ March 1872 \\
\hline D Steel, Esq & $\begin{array}{l}\text { Pergunnah Burkhola mouza, } \\
\text { Shubong }\end{array}$ & 1230120 & $13^{\text {th }}$ April 1872 \\
\hline H W Craigie, Esq & $\begin{array}{l}\text { Pergunnah } \begin{array}{l}\text { Luckipore, } \\
\text { mouzah Homickpore }\end{array}\end{array}$ & 50000 & $18^{\text {th }}$ April 1872 \\
\hline $\begin{array}{l}\text { C A Alexander, } \\
\text { Esq }\end{array}$ & $\begin{array}{l}\text { Pergunnah Sorrispore, } \\
\text { mouza, Bhaugulpore }\end{array}$ & 1030226 & $29^{\text {th }}$ April 1872 \\
\hline $\begin{array}{l}\text { Krishna Govind } \\
\text { Deb, Vakeel on } \\
\text { behalf of Mr. C } \\
\text { Harione }\end{array}$ & Pergunnah Luckimpore & 1893120 & $22^{\text {nd }}$ August 1872 \\
\hline W Hall, Esq & Pergunnah Luckipore & 103221 & $3^{\text {rd }}$ May 1872 \\
\hline
\end{tabular}

It also appears from the letter that, one Bengali gentleman named Purbatty Charan Benerjee, Banker and Agent, Sylhet had correspondence with R Stewart, Suprintendent of Cachar, seeking grant of land for tea cultivation. ${ }^{22}$ But it was not clear whether he himself had withdrawn from the field or his claim remained unrecognized by the authorities.

\section{Development of Tea Garden in Cachar}

The tea plantation, thus, gradually developed all throughout Cachar and in course of time, with the liberal grants of land on easy terms, the expansion of tea plantation occurred throughout the province. By the end of the $19^{\text {th }}$ century, as many as two hundred tea gardens were opened in Cachar. According to the sources recorded in the Director of Agriculture, Assam and Indian Tea Statistics, Government of India, up to the year 1947, the total number of tea estates in colonial Cachar was 231 with a total land area of 75,000 acres and

${ }^{21}$ Government letter written by O G R Macwilliam, Offg. Deputy Commissioner, Cachar, dated $19^{\text {th }}$ August 1872State Archives and Record Room, Gauhati, File No. 102-198 BG

$2223^{\text {rd }}$ July 1855, District Record Room, Silchar 
labourers of $75,992 .{ }^{23}$ The following table represents the development of the tea industry in Cachar prior to its commencement till 1947.

TABLE - 3 Development of Tea Gardens in Cachar

\begin{tabular}{|l|l|l|l|}
\hline Year & Number of Gardens & $\begin{array}{l}\text { Total Area } \\
\text { (In Acres) }\end{array}$ & $\begin{array}{l}\text { Area Under Plantation } \\
\text { (In Acres) }\end{array}$ \\
\hline 1861 & 54 & 80,000 & 16,000 \\
\hline 1869 & 71 & 86,000 & 24151 \\
\hline 1872 & 80 & 91,000 & 23,000 \\
\hline 1882 & 150 & NA & 48,873 \\
\hline 1895 & 199 & 280172 & 58216 \\
\hline 1898 & 190 & 270831 & NA \\
\hline 1899 & 187 & 272892 & NA \\
\hline 1901 & 180 & NA & 56000 \\
\hline 1915 & 159 & 277033 & 60549 \\
\hline 1942 & 233 & NA & 75000 \\
\hline 1943 & 235 & NA & 75000 \\
\hline 1944 & 235 & NA & 75100 \\
\hline 1945 & 235 & NA & 75100 \\
\hline 1946 & 235 & NA & 75000 \\
\hline 1947 & 231 & NA & 75300 \\
\hline
\end{tabular}

Source - State Archives and Record Room, Guwahati and District Record Room, Silchar NA - Not Available.

It is to be mentioned in this connection that, though the tea plantation of Cachar had gradually developed, it cannot be denied that, the Planters and entrepreneurs were not free from the upcoming problems. Among the various major problems, the foremost was the scarcity of skilled labourers and the raids made out by the neighbouring tribes in the newly established tea gardens.

\section{Reasons Behind The Clash Between English And The Tribes}

After the discovery of the tea plantation in Cachar in 1855 in Mauza Barsangan, present Kathal Bagan, the English East India Company invited the European Companies and capitalists to take to its cultivation with easy leases. ${ }^{24}$ This led to the establishment of a large number of tea gardens in a gradual process and within a very short span of time most of the important areas of waste lands were covered with tea plantations. Thus, large number of tea gardens emerged accordingly during the last quarter of the $19^{\text {th }}$ century. It is interesting to note here that, "During the days of 'mad mania' for cultivation of tea large plots of waste land were sold in London to when the authorities came to look they found the plots were in a tract which the government acknowledged to be a part of Lushai village lands. The lessee therefore, could not be put in possession of the lands. ${ }^{, 25}$

In the last decade of the $19^{\text {th }}$ century there was considerable expansion and production of tea. In 1881, total acreage under tea plant was 24,151 acres which increased to 62,179 acres in $1898 .^{26}$ The British occupation of the land for expansion of tea cultivation made the land unavailable to the tribal people. The total area of land taken by the tea planters rapidly increased within a very short period of time. From 3,71,990 acres in 1872 it increased to $16,29,524$ in $1928 .{ }^{27}$ Following table gives some data in this regard. ${ }^{28}$

TABLE - 4 Land taken for Tea Cultivation

\begin{tabular}{|l|l|l|}
\hline Year & $\begin{array}{l}\text { Total Area taken up by tea } \\
\text { planters }\end{array}$ & Area under actual tea cultivation \\
\hline 1872 & 331990 Acres & 2800 Acres \\
\hline
\end{tabular}

23 State Archives and Record Room, Guwahati also 'Report on an enquiry into the family budget of tea garden workers in Assam, 1951-52', Deptt. of Economics and Statistics, Govt. of Assam, Shillong, 27 $7^{\text {th }}$ Oct.1953, p.16

${ }^{24}$ File No- 103-199 BG State Archives and Record Room, Guwahati.

25 Assam Secretariat Archives (ASA), Report on Matters Regarding the Disposal of Waste Land in Bengal, 25 ${ }^{\text {th }}$ July, 1871, p.2

${ }^{26}$ Allen, B C, Assam District Gazetteers, Vol-I, Cachar, 1905, p.78

${ }^{27}$ Goswami, Arup Kumar, Extension of tea cultivation and its impact on the neighbouring tribes, , in journal of Noth East India Council for Social Science Research, p.198

${ }^{28}$ Ibid. 


\begin{tabular}{|l|l|l|}
\hline 1878 & 587409 Acres & 147840 Acres \\
\hline 1885 & 921891 Acres & 197510 Acres \\
\hline 1895 & 1065268 Acres & 276014 Acres \\
\hline 1915 & 1323619 Acres & 383821 Acres \\
\hline 1928 & 1629524 Acres & 427225 Acres \\
\hline
\end{tabular}

Thus, the large scale expansion of tea cultivation and the granting of wasteland with easy leases by the authority for the tea cultivation, in many cases, led to the encroachment of the land belonging to the wild tribes by the tea Planters which seriously affected the economy and livelihood of the tribal people. This disturbed the bordering between settled British territory and the territories of independent tribes, leading to conflict. The Lushais, on their part, reacted to this with nothing but raided on the tea plantation in plain Cachar by burning villages and killing people. Such behaviour on the part of the tribes invited British retaliations.

The tea Planters considered that they had a legal right over their gardens, while the Chief of the nearest tribe claimed themselves to be free and sovereign people, who exercised authority in the plains of the foothills. They believed themselves to be the lord of the manor, because their ancestors had for generations roamed or hunted or levied dues or had been buried in that part of the countryside. ${ }^{29}$

It is also being noted here that, not only tea, even timber was being extracted from the tribal lands. For the tribal people, elephant played a major role for their livelihood, which they caught from the hills. But the Government of British India began to permit non tribals to catch elephants from the hills to plain thereby depriving the Lushais of their traditional livelihood. ${ }^{30}$ This annoyed the tribals very much and they expressed their anger by repeated raids upon the plains.

In addition to tea, the British invested their capital in oil, coal etc. for this they required the security for their capital. ${ }^{31}$ The tribal raids were therefore found harmful to their interest and a permanent solution to the problem was felt necessary.

In this way, the extension of tea cultivation affected the socio-economic life of the neighbouring tribes. The British Government was very much conscious to protect their economic interest while the tribes were also not ready to sacrifice their traditional right on land. This ultimately led to clashes between them. The advancement of the English towards the hills was seen as a threat to their very existence and they took it not only as an encroachment but also an invasion into their territory. They ultimately realized that the day was not far when the English would penetrate the hills and take away their freedom. They, therefore, started reaction against the British rulers in the form of violence, raids on the tea plantations, burning villages, killing people and committing other atrocities. The British Government, on the other side adopted non-intervention policy in the beginning of their rule with regard to the tribes of North-East-India. ${ }^{32}$ Even an expansionist like Lord Dalhousie wanted to leave the hill men to themselves and followed a peaceful policy towards them. The situation, however, changed drastically with the expansion of tea cultivation and growth of other economic interest of the Government in the hills and the border areas. As a reaction to the repeated outrages by the tribes and the consequent insecurity of the entire frontier, ultimately the non-intervention policy was replaced by a policy of intervention, which is steady penetration into the hills. It is also imperative to prevent the recurrences of these outrages and in any case to bring the actual perpetrators to look. ${ }^{33}$ The Government of India, Foreign Department accorded its approval to the forward policy on June $7^{\text {th }} 1866$ and henceforth stern retaliatory measures were taken by the government against the tribes. ${ }^{34}$

\section{Background Of Lushai Tribes}

The hills lying to the south of the Cachar Valley were inhabited by various tribes known to the Bengalis by the generic name of Kuki. ${ }^{35}$ In the initial stages, the Kukis, emerging from the Lushai Hills, now called Mizoram, created havoc in the southern portion of the region. Villages, which were growing up in the area were plundered and the plains people fled away to the northern bank of the Barak, in consequence of

${ }^{29}$ Goswami, Arup Kumar, Extension of tea cultivation and its impact on the neighbouring tribes, in journal of Noth East India Council for Social Science Research, p.197.

${ }^{30}$ Ibid, p.47

${ }^{31}$ Goswami, Arup Kumar, Extension of tea cultivation and its impact on the neighbouring tribes, in journal of Noth East India Council for Social Science Research, p..202.

${ }^{32}$ Goswami, Arup Kumar, Extension of tea cultivation and its impact on the neighbouring tribes, in journal of Noth East India Council for Social Science Research, p.199.

${ }^{33}$ Barpujari, H K, The Comprehensive History of Assam, Vol IV, Guwahati, 1993, p.159.

34 Ibid.

${ }^{35}$ Gait, Sir Edward, A History of Assam, Surjeet Publication, N Delhi, 2006, p.369. 
which, this region turned into a dense forests. ${ }^{36}$ As a solution of this problem, Captain Fisher settled Manipuris on the southern border of Cachar with the hope that the Manipuris being vigorous and courageous would be able to resist the Kuki raids. ${ }^{37}$ However, the Kuki raids continued till the forties when the Kuki themselves being driven out from the Lushai Hills by the Lushais who got scattered on the hills in the east and the north. ${ }^{38}$ With disappearance of the Kuki menace, the lace of the Kukis was taken by the Lushais, who made their first appearance on this frontier about the year 1840 with their great leader Lalal ${ }^{39}$ It was the descendants of Lalal that lately been the cause of anxiety to the British government. The Lushais committed their first raid in 1849 and the punitive expedition which followed was so successful that they gave no further trouble until $1868 .{ }^{40}$

The term Lushai was first mentioned by Lieutenant Colonel Lister, Political Agent of the Khasi Hills, who make a statement regarding Lushais that they appeared to be a cross between the Kukies and the Burmese ${ }^{41}$ Lushai is a compound word consisting of two component words, Lu (meaning 'head') and shai (meaning 'to cut'), meaning of which is the head cutter. ${ }^{42}$ The reasons behind the head hunting among these tribes, Dr. J B Bhattacharjee says, 'It was an art of chivalry affording them the greatest delight and social distinction as a man's importance was calculated by the number of skulls decorating his house and according to their custom, the funeral of the chiefs required a certain number of skulls. ${ }^{43}$ The Lushai (now called Mizos) were a sturdy tribal people living on hunting, fishing, food gathering and slash and burn cultivation called jhuming. ${ }^{44}$ Often they committed raids, plunders, kidnapping and head hunting on the people of the foothills. Because of their nature of settlement, they were mostly depended on the plains for their livelihood. The increasing difficult life of the hills, an increasing population and shortage of cultivable land made the wild tribes come down to the foothills for their natural outlets, which were not available in the hills. Some scholars mentioned that, the plains were also a happy hunting ground for the tribes for the perpetration of raids, kidnapping, head-hunting and slave procurement. ${ }^{45}$ Raids were committed to meet the needs of agricultural and handicraft products. Kidnapping was done to enhance the manpower for tribal economy and the kidnapping of women were specially done for the tribal Chiefs who made them their wives and servants and through these acts they proved their might. Lastly, head-hunting was necessary to obtain human heads for the funeral rites of Chiefs. Thus, the Lushais had selfassumed authority over the foothills, plains and villages where they committed regular raids. They not only considered raids as a display of their authority, but also imposed tax collection on these villages which terror stricken villagers had to pay. ${ }^{46}$

\section{The Confrontation}

The first raid is recorded in Cachar during the British period in the year 1849 when the Lushais committed a violent raid in the village Rupcherra, in which 29 persons were killed and 42 carried off captive. ${ }^{47}$ To put a stop to future aggression, Lieutenant Colonel Lister, Political Agent of the Khasi Hills was directed to proceed against the hill tribes and asked to take necessary steps and if possible punish them. Accordingly, in the following year i.e. 1850, Lister conducted a strong punitive expedition consisting of the Sylhet Light Infantry and 150 Armed Civil Police. He entered the Lushai country and destroyed the village of Mulla, one Lushai Chief. ${ }^{48}$ But when he found that the Lushais were more powerful and numerous than he expected, he then thought it better to retire. However, strong outposts were then established and every effort was maintained to keep out the Lushais from the raids. This resulted in a phase of peace and quiet and the area was stable for about 12 years.

After a period of 12 years there were again numerous other raids committed by the Lushais and at the same time the British retorted by sending expeditions to chastise them. By the 1860s, the Lushais attacked the

${ }^{36}$ Cachar District Gazetteer, Govt. of Assam, Gauhati, p.49

${ }^{37}$ Gait, Sir Edward, A History of Assam, Surjeet Publication, N Delhi, 2006, p.357.

${ }^{38}$ Cachar District Gazetteer, Govt. of Assam, Gauhati, p.49

${ }^{39}$ Thorpe, G Wood, The Lushai Expedition 1871-1872, Hust and Blackett Publishers, London, 1873, p.10.

${ }^{40}$ Ibid, p. 15 .

${ }^{41}$ Meckenzie, Alexander, British Relation with the Hill Tribes of North-East-Frontier of Bengal, Kolkata, 1884, p.293.

${ }^{42}$ Mohonto, Bibekanand, Unis Sataker Lushai Abhijan o Dholeswari Upatyakar Katlacherra: Ekti Parjalochan, in a Teacher magazine, Hailakandi, 2012, p.33.

${ }^{43}$ Bhattacharjee, J.B., Cachar Under British Rule in North East India, New Delhi, 1977. P.113

${ }^{44}$ Chatterjee, Suhas, Mizo Chiefs and the Chiefdom, M D Publications, New Delhi, 1995, p.6.

${ }^{45} \mathrm{Nag}$, Sajal, Contesting Marginality - Ethnicity, Insurgence and Sub-nationalism in North-East-India, Published by Ajay Kumar Jain, New Delhi, 2002, p.41

${ }^{46}$ Ibid, p.43

${ }^{47}$ Allen, B C, Assam District Gazetteers, Vol - I, Cachar, Shillong, 1905, p.36

${ }^{48}$ Bhattacharjee, J B, Cachar Under British Rule in North-East-India, New Delhi, 1977, p.98 
plains of Cachar again, specially the tea gardens. On $23^{\text {rd }}$ January 1862 the village of Adampore in present Sylhet was attacked and burnt. ${ }^{49}$ In 1863 another raid took place in Chandraipur. ${ }^{50}$ In 1868-69 a series of outrages were made, mention may be made to the garden of Loharbond and Moniarkhal in Cachar. The garden of Loharbond was burnt, several inhabitants were killed and carried away many others pushed into slavery. Monierkhal, on the other hand, was attacked by Lushais in $15^{\text {th }}$ January $1869 .{ }^{51}$ This garden is situated on the Sonai river, about 20 miles south of the Sudder station of Silchar, held under the ordinary Meerasdaree yearly rent paying pottah of the district. ${ }^{52}$ On $15^{\text {th }}$ January 1869 , very early in the morning, the Lushais attacked the garden in large numbers and soon the garden speedily fell into their hands. ${ }^{53}$ After burning the garden and taking with them everything, the Lushais departed. This attack created panic among the coolies. The loss resulting from this raid was very serious, amounting not less than Rupees 17,000 in all. ${ }^{54}$ Nearly Rupees 3,500 of this has fallen directly upon the coolies, who lost all their clothes, brass vessels and live stock, besides over Rupees 2,000 in cash. ${ }^{55}$ This attack killed nine coolies including three children and the two resident Europeans had to flee for their lives nearly naked. The remaining coolies were dispersed into the jungles. ${ }^{56}$

It is found from the sources that, the tea company named Messers. Jardine, Skinner and Company communicated with the Secretary to the Government of Bengal ${ }^{57}$ and Secretary to the Government of India ${ }^{58}$ in two different letters, praying for compensation in respect of the losses sustained by the Lushai's attack on January 18, 1869 in Monierkhal Tea Garden in Cachar. In its response to these letters, the Government was unable to uphold the claim for compensation from the public revenues for the losses in question. ${ }^{59}$

This was then followed by an expedition launched by the British which was soon dispatched into the hills, but because of the difficulties of the hilly terrain and the unfavourable weather, the expedition again returned without accomplishing anything. ${ }^{60}$ In December 1869 Mr. Edgar, the Deputy Commissioner, Cachar, made a tour into the Lushai Hills and succeeded in forming good relations with the hillmen by making a treaty with the Mizo Chief Sukpial. ${ }^{61}$ But this treaty was short lived and within a span of a year after his return, the Lushais once again started their raid on the foothills.

In the beginning of the year 1871, the Lushais came down from their hills with great force and a series of attacks were simultaneously made on tea gardens of Cachar and Sylhet namely - Ainakhal, Alexandrapore, Katlichera, Moniarkhal, Dharmikhal and Nagdirgram. The last raid was made on Jhalanchera Garden and during these raids there was a large scale of destruction and killing. ${ }^{62}$

In Cachar, the raiders threatened the whole of the southern part of the District for several days. In January 1871, the tea village of Ainakhal in the south of the Hailakandi Valley was attacked, when 25 persons were killed and 37 taken prisoner. ${ }^{63}$ The raid of Alexandrapur tea garden was made on $27^{\text {th }}$ January $1871 .{ }^{64}$ This was organized

${ }^{49}$ Chatterjee, Suhas, Mizo Chiefs and the Chiefdom, M D Publications, N. Delhi, 1995, p.7

$50 \mathrm{Nag}$, Sajal, Contesting Marginality - ethnicity, insurgence and sub-nationalism in North-East-India, Published by Ajay Kumar Jain, New Delhi, 2002, p.48

${ }^{51}$ Home Department (Public) Proceedings, July24, 1869, NAI, Letter dated 22 ${ }^{\text {nd }}$ May 1869, from Messers. Jardine, Skinner and Company to the Hon'ble A Eden, Secretary to the Government of Bengal, No.11.

52 Ibid.

${ }^{53}$ Ibid.

${ }^{54}$ Home Department (Public) Proceedings, July24, 1869, NAI, Letter dated Simla, the $19^{\text {th }}$ July 1869 , from J Geoghegan, Esq, Under Secretary to the Government of India to the Hon'ble A Eden, Secretary to the Government of Bengal, Judicial Department, No.3355.

${ }^{55}$ Ibid.

${ }^{56}$ Home Department (Public) Proceedings, July24, 1869, NAI, Letter dated 22 ${ }^{\text {nd }}$ May 1869, from Messers. Jardine, Skinner and Company to the Hon'ble A Eden, Secretary to the Government of Bengal, No.11.

${ }^{57}$ Ibid

${ }^{58}$ Home Department (Public) Proceedings, July24, 1869, NAI, Letter dated $25^{\text {th }}$ June 1869, from Messers. Jardine, Skinner and Company to the Hon'ble E C Bayley, Secretary to the Government of India, Simla, No.24.

${ }^{59}$ Home Department (Public) Proceedings, July24, 1869, NAI, Letter dated $27^{\text {th }}$ May 1869, from A Mackenzie, Esquire, Officiating Junior Secretary to the Government of Bengal to Messers. Jardine, Skinner and Company, No.3640.

${ }^{60}$ Allen, B C, Assam District Gazetteers, Vol - I, Cachar, Shillong, 1905, p.36

61 Ibid.

${ }^{62}$ Cachar District Gazetteer, Govt. of Assam, Gauhati, p.49

63 Allen, B C, Assam District Gazetteers, Vol - I, Cachar, 1905, p.37 and also Nag, Sajal, Contesting Marginality - ethnicity, insurgence and sub-nationalism in North-East-India, Published by Ajay Kumar Jain, New Delhi, 2002, p.48

${ }^{64}$ Chatterjee, Suhas, Mizo Chiefs and the Chiefdom, M D Publications, N. Delhi, 1995, p.7 
by a prominent chief called Bengkhuaia, who ruled over the villages of Serchhip, Sailam, Kawiri and Thenzawl. He had the reputation of being a good and popular chief. That day Mr. Seller, the owner of the Alexandrapore tea garden and his friend Mr. James Winchester, a Scottish tea garden manager of another tea garden were taking breakfast at Mr. Seller's Bunglow. ${ }^{65}$ Suddenly, the Lushais burst upon the tea garden and there was no choice but to fly to the jungle. Mr. Winchester, carried his daughter Mary and ran for his life, but, was killed. Mary, a girl of 6 or 7 years old was carried off by the Lushais as a hostage. ${ }^{66} \mathrm{Mr}$. Seller succeeded in making his escape. ${ }^{67} \mathrm{~A}$ few hours later, an attack was made on the neighbouring garden of Katlicherra. ${ }^{68}$ Though the raiders were driven off by the labourers or natives from the tea garden, yet, they succeeded in killing five coolies and wounded people in great numbers. ${ }^{69}$ The attack was renewed on the following day but the Lushais were again beaten off. ${ }^{70}$ Three days later Moniarkhal, which is situated on the Sonai near the eastern frontier of the district, was attacked. The defenders were relieved by a party of sepoys and police under the District Superintendent of Police Mr. Daly and on the second day the Lushais were driven off with a loss of 57 men. ${ }^{71}$ While the attack on Moniarkhal was going on, another party of these savages raided the gardens of Dharmikhal and Nagdergram, where 11 persons were killed in the latter estate and 3 persons were captured as prisoners. ${ }^{72}$ On the following day, a party of troops and police, who had been sent to the relief of Moniarkhal were attacked near Nagdirgram, where 6 out of 8 sepoys were killed..$^{73}$ The last raid was made on the Jhalancherra Tea Garden on $23^{\text {rd }}$ February $18711^{74}$

According to the sources, at about $7 \mathrm{AM}$ on the $23^{\text {rd }}$ February 1871, a number of Lushais crossed the river Dhullapur and entered the coolie lines of the garden. ${ }^{75}$ They seemed to have had a number of guns, usual spears and daos. Several men wore red pagris and some wore a black khesh. ${ }^{76}$ The Manager of the garden calculated the number of Lushais at about $150 .^{77}$ While the Lushais entered the coolie lines of the tea garden, one head and four constable, who were patrolling in the garden opened fire at once and as the firing was heard, soon relief came from the garden and the Lushais were driven back across the river without much success. ${ }^{78}$ The constables succeeded to repulse the Lushais, but not before they had killed one Bengali boatman and two coolies and wounded five others. ${ }^{79}$ The houses of Jamedar and Baboo, employed in the garden were plundered, but nothing of any great value seemed to have been taken. ${ }^{80}$ The Government of British India rewarded certain members of the police for their outstanding conduct in repelling the attack on the Jhalencherra Tea Garden. ${ }^{81}$

\section{British Expedition Against The Lushais}

It now became absolutely necessary that a vigorous effort should be made to put an end once for all to these inroads. Accordingly, a strong military and police force was stationed within the Cachar province and a line of patrol was set up. It was also decided to send an expedition against the Lushais in the cold season, the only time of the year when military operations could be conducted on the region. The details of the expedition

${ }^{65}$ Hunter, W W, Statistical Account of Assam, Vol - 2, Trubener and Company, London, 1879, p.388.

${ }^{66}$ Allen, B C, Assam District Gazetteers, Vol - I, Cachar, Shillong, 1905, p.37

${ }^{67}$ Hunter, $W W$, 'Statistical Account of Assam', Vol - 2, Trubener and Company, London, 1879, p.388

${ }^{68}$ Allen, B C, Assam District Gazetteers, Vol - I, Cachar, Shillong, 1905, p.37

${ }^{69}$ Ibid.

${ }^{70} \mathrm{Ibid}$

${ }^{71}$ Ibid.

${ }^{72}$ Ibid.

${ }^{73}$ Ibid.

${ }_{75}^{74}$ File No. - 267/538 (Govt. of Bengal), State Archives, Gauhati.

75 Government of Bengal (Judicial), File no.538, May 1871, letter written from W W Daly, Esq. District Superintendent of Police, Cachar to the Personal Assistant to the Inspector-General of Police, Lower Province, dated Cachar $6^{\text {th }}$ March 1871.

${ }^{76}$ Government of Bengal (Judicial), File no. 538, March 1871, a report from Mr. Daly, District Superintendent of Cachar giving the particulars on attack made by Lushais on the Jhalancherra Tea Garden on $23^{\text {rd }}$ February 1871.

${ }^{77} \mathrm{Ibid}$

${ }^{78}$ Government of Bengal (Judicial), File no.538, May 1871, letter written from W W Daly, Esq. District Superintendent of Police, Cachar to the Personal Assistant to the Inspector-General of Police, Lower Province, dated Cachar $6^{\text {th }}$ March 1871.

${ }^{79}$ Ibid.

${ }^{80} \mathrm{Ibid}$

${ }^{81}$ Letter from H Lepoer Wynne, Esq. Under Secretary to the Government of India, Foreign Department to the Hon'ble A Eden, Secretary to the Government of Bengal, Judicial Department, No.588P, dated Fort William, the $23^{\text {rd }}$ March 1871 . 
were arranged by the Commander-in-chief and an overwhelming force was organized to subjugate the tribes. The army was composed of the $2^{\text {nd }}$ and $4^{\text {th }}$ Gurkha Regiments, the $22^{\text {nd }}$ and $27^{\text {th }}$ Punjab Infantry, the $42^{\text {nd }}$ and $44^{\text {th }}$ Native Infantry, two companies of Sappers and Miners and a strong detachment of the Peshwar Mountain Battery ${ }^{82}$ This was divided into two groups - the first under the command of Brigadier General G. Bourchier, who was to advance from Cachar and the second, commanded by Brigadier General C H Browlon, who was to enter the Haulong territory by way of Chittagong frontier. ${ }^{83}$

According to the plan, the British attacked the Lushais from both sides and in this attack, the Lushais were unable to resist and there was enormous destruction and death. The expeditions were completely successful when the Lushai Chiefs - Savunga, Langura, Lalzika and Benkhuaia surrendered to the British. ${ }^{84}$ As a result of their surrender there was relative peace in Anglo-Lushai relations. General Brownlow in his report briefly summed up the results of the expedition which were as follows - 'the complete subjection of two powerful tribes inhabiting 60 villages of which 20 were attacked and destroyed, the personal submission of 15 Chiefs, the recovery of Mary Winchester including 100 Britishers who have been made captives, the total loss on the English side throughout the campaign was 12 fighting man killed and 27 wounded. ${ }^{85}$

Since the date of this expedition, the Lushais remained quiet for a long time on the frontier and the English hoped that the punishment that was imposed on them had the desired effect. Steps were also taken to promote commercial intercourse between the hillmen and the people of the plains. But, in the subsequent year, the peace as maintained by them become short lived and it held good only for 20 years. During this period, with the death or aging of the Chiefs, the younger leaders took the charge and they realized that the only way to get back their earlier freedom was to overthrow the British. To disturb the British, they stole cattle from the British camps, destroyed vegetable gardens and cut telegraph cables - all these were done to express their resentment. Their discontent was displayed vehemently when in $4^{\text {th }}$ April 1892 a party of Lushais raided the garden of Barunchara ${ }^{86}$ They burnt 5 houses, killed 42 labourers and mutilated many. However, this raid was repulsed and the rising was put down without any trouble. In 1893, another tragic incident took place when the Lushai attacked the Baladhan Tea Estate, a garden more than 80 miles away in the North-East corner of the Cachar plains. ${ }^{87}$ At midnight, some people entered the Bungalow, murdered the European Manager Mr. Blyth, Chawkidar, and 16 or 17 coolies. A woman who lived in the bungalow was mortally wounded.

Seeing the brutal raiding of the Lushai tribes, the British decided to bring the Lushai tribes under their control and rule them from the heart of the Lushai Hills. As such, in 1891, with the effort made by the English, the entire Mizo Hills was annexed to British India and placed under British administration. Thus, the history of Lushai resistance which was a great threat for British-India came to an end on $27^{\text {th }}$ January 1898 when the Lushai Hills was placed under the charge of a superintendent with headquarters at Aizawal and the first Superintendent of Mizo Hills was Colonel J Shakespear $(1898-1905){ }^{88}$

\section{Conclusion}

Thus, we see that the extension of tea cultivation affected the socio-economic life of the neighboring Lushai tribes. The British Government was very much conscious to protect their economic interest, while the Lushai tribes were also not ready to sacrifice their traditional right on land (plain Cachar). This ultimately led to clashes between them. The British Government therefore, adopted a repressive policy against the tribes, this ultimately led to the annexation of Lushai Hills on $27^{\text {th }}$ January 1898.

\footnotetext{
${ }^{82}$ Hunter, WW, Statistical Account of Assam, Vol - 2, Trubener and Company, London, 1879, p.389.

${ }^{83}$ Ibid.

${ }^{84} \mathrm{Nag}$, Sajal, Contesting Marginality - Ethnicity, Insurgence and Sub-nationalism in North-East-India, New Delhi, 2002 , p.48.

${ }^{85}$ Hunter, W W, Statistical Account of Assam, Vol - 2, Trubener and Company, London, 1879, p.392

${ }^{86}$ Allen, B C, Assam District Gazetteers, Vol-I, Cachar, Shilling, 1905, p.38.

${ }^{87}$ Ibid, p.39

${ }^{88}$ Chatterjee, Suhas, Mizo Chiefs and the Chiefdom, M D Publications, N. Delhi, 1995, p.8 
1. PRIMARY SOURCES

\section{References}

\section{A. UNPUBLISHED}

i. District Record Room, Silchar (1834-1900)

These includes volumes and files of letters received and written by the Superintendent and Deputy Commissioner of Cachar. ii. State Archives and Record Room, Guwahati

Pre 1874 Files:-

Bengal Government Files.

Bengal Board of Revenue Files.

Dacca Commissioners File.

Assam Commissioners File.

Assam Secretariat Proceedings (Department of Revenue, Agriculture and Commerce), since 1875.

Home Department Proceedings (Public, General, Judicial, Revenue, Forests), since 1868.

\section{iii. West Bengal State Archives, Kolkata}

Proceedings of the Judicial Department, Emigration Branch, 1873.

Allen, W J, Report on the administration of Cachar, No. 1002, Cherapunjee, 1858.

iv. National Archives, New Delhi

Home Department, since 1858

Proceedings of the Department of Revenue and agriculture, since 1860.

B. PUBLISHED (Documents and Reports)

Report on an Enquiry into the Family Budget of the Tea Garden Workers in Assam 1951-1952 - S C Sharma, Deptt. of Economics and Statistics, Assam, 1953.

Report on Tea Culture in Assam, Shillong, 1900.

Cachar District Gazetteer.

Detailed Report of the General Committee of the Indian Tea Association, Kolkata, 1897.

Assam Administration Report.

Report of the Assam Labor Enquiry Committee, 1906.

\section{SECONDARY SOURCES}

A. BOOKS -

B.C. Allen (a), Assam District Gazetteers, (Vol-I, Cachar, Shillong, 1905).

B.C. Allen (b), Assam District Gazetteers, (Vol-V, Kamrup, Shillong, 1905.

H.A. Antrobus, A History of Assam Company 1839-1953, (T and A Constable Ltd. Edinburg, 1957).

R.C. Awasthi, Economics of Tea Industry in India - with Special Reference to Assam, (United Publisher, Guwahati, 1975).

S. Barkakati, Assam, (National Book Trust, India, N Delhi, 1969).

H.K. Barpujari (a), Assam in the Days of the Company (1826-1858), (Guwahati, 1980).

H.K. Barpujari (b), The Comprehensive History of Assam, (Vol-V, Guwahati, 1993).

D.N. Barua,, Science and Practice in Tea Culture, (Tea Research Association, Kolkata, 1989).

P. Baruah, The Tea Industry of Assam - Origin and Development, (EBH Publishers India, Gauhati, 2008).

G. Benerjee, Tea Plantation Industry Between 1850-1992 Structural Changes, (K N Dutta Baruah, Gauhati, 1996)

J.B. Bhattacharjee (a), Cachar under British Rule in North East India, (Radiant, New Delhi, 1977).

J.B. Bhattacharjee (b), Trade and Colony: The British Colonization of North East India, (Shillong, 2000).

J.B. Bhattacharjee (c), Development Strategies for Barak Valley (Assam), (Akansha Publishing House, N Delhi, 2009).

S. Chatterjee, Mizo Chiefs and the Chiefdom, (M D Publications, N Delhi, 1995).

R. Dey, Land Revenue Administration in Cachar: 1832-1900, (Biswabani Prakashani, Kolkata, 2001).

D. Dutta, History of Assam, (Sribhumi Publication, Kolkata, 1989).

D. Dutta, Cachar District Records, Silchar, 1969

E.A. Gait, A History of Assam, (Surjeet Publication, N Delhi, 2006 (Reprint).

P. Goswami, Assam in the Nineteenth Century: Industrialization and Colonial Penetration, (Spectrum Publications, New Delhi, 1999).

P. Griffiths, The History of the Indian Tea Industry, (Weidhnfeld and Nicolson, London, 1967).

A. Guha, Planters Raj to Swaraj Freedom Struggle and Electoral Politics in Assam 1826-1947, (Indian Council of Historical Research, N Delhi, 1977).

Hunter, W.W., A Statistical Account of Assam Vol-II, (Trubener and Company, London, 1879).

J.C. Jha, Aspects of Indenture Inland Emigration to North-East-India 1859-1918, (Indus Publishing Company, N Delhi, 1996).

G. Kaushal, Economic History of India, (Kalyani Publishers, N Delhi, 1991).

A. Meckenzie, British Relation with the Hill Tribes of North-East-Frontier of Bengal, (Kolkata, 1884).

S. Nag, Contesting Mrginality - Ethnicity, Insurgence and Subnationalism in Nort-East-India, (Published by Ajay Kumar Jain, N Delhi, 2002).

A.C.Phukan, Personal Administration in the Tea Industry of Assam, (Archita Publication, Assam, 1979).

U. Phukan, The Ex-tea Garden Labour Population in Assam (A Socio-Economic Study), (B R Publishing Corporation, Delhi, 1984).

B.B. Sen, Origin and Development of Tea, (EBH Publishers India, Gauhati, 2008).

S.N. Singh, Socio-Economic and Political Problems of Tea Garden Workers - A Study of Assam, (Mittal Publication, N Delhi, 2006).

G.W. Thorpe, The Lushai Expedition 1871-1872, (Hurst and Blacket Publishers, London, 1873).

\section{B. ARTICLES}

P. Kumar Tea plantation workers of Cachar: A socio-political study, North East Council for Social Science Research, $28(2), 2004$.

R. Dey, Tea holding to absentee ownership: Chatla pargana in the Barak Valley, North East India History Association, $17,1996$.

R. Dey, Tea Labourers in the Barak Valley, North East India History Association, 9, 1988.

R. Dey, A study on the emergence of ex-tea garden labour colonies in Chatla pargana of Barak Valley with special reference to Tarutajabari revenue village, North East India History Association, 18, 1997.

R. Dey, Settlement on land of the North East India Silchar tahsil Under colonial regime, North East India History Association, 6, 1985.

R. Dey, Origin of Silchar as the Sadar Station of Cachar, North East India History Association, 5, 1984.

R. Dey, Some aspects of forest administration in Cachar under the British rule, North East India History Association, $13,1992$.

D. Dutta, Beginning of the Tea industry in Cachar”, Purbashree, Silchar. 
S. Dutta, Historic and pioneering role of the Singphos in tea cultivation of the North-East, North East India History Association, $15,1994$.

S.K. Ghosh, Labour strike in the Surma valley tea gardens, North East India, 7, 1986.

S.K. Ghosh, Glimpses of Socio-Cultural Life in Medieval Cachar, 1, 1980.

A.K. Goswami, Extension of tea cultivation and its impact on the neighbouring tribes, 25, 2004

Goswami, Priyam, Socio-economic impact of tea industry in Upper Assam (1839-1911), 1, 1980.

Mehra, S K, Knowing the tea industry.

S. Pio, Identity problems among tea garden labourers in Assam, 13, 1992

S. Pio, Tea plantation protection force - A critical approach, 14, 1993.

Saha, Subhash, Capital-labour relation: A study of tea plantation in Assam (1835-1926), 7, 1986.

W.H.S. Wood, Tea in Cachar, Assam Review, 1929.

\section{SOUVENIR}

Assam Branch Indian Tea Association (1889- 1989), a Centenary Souvenir published from Silchar.

Surma Valley Branch Indian Tea Association (1901-2001), a Centenary Souvenir published from Silchar.

'Karwa', a Souvenir published from the Roskandi Tea Estate, Silchar, 2010.

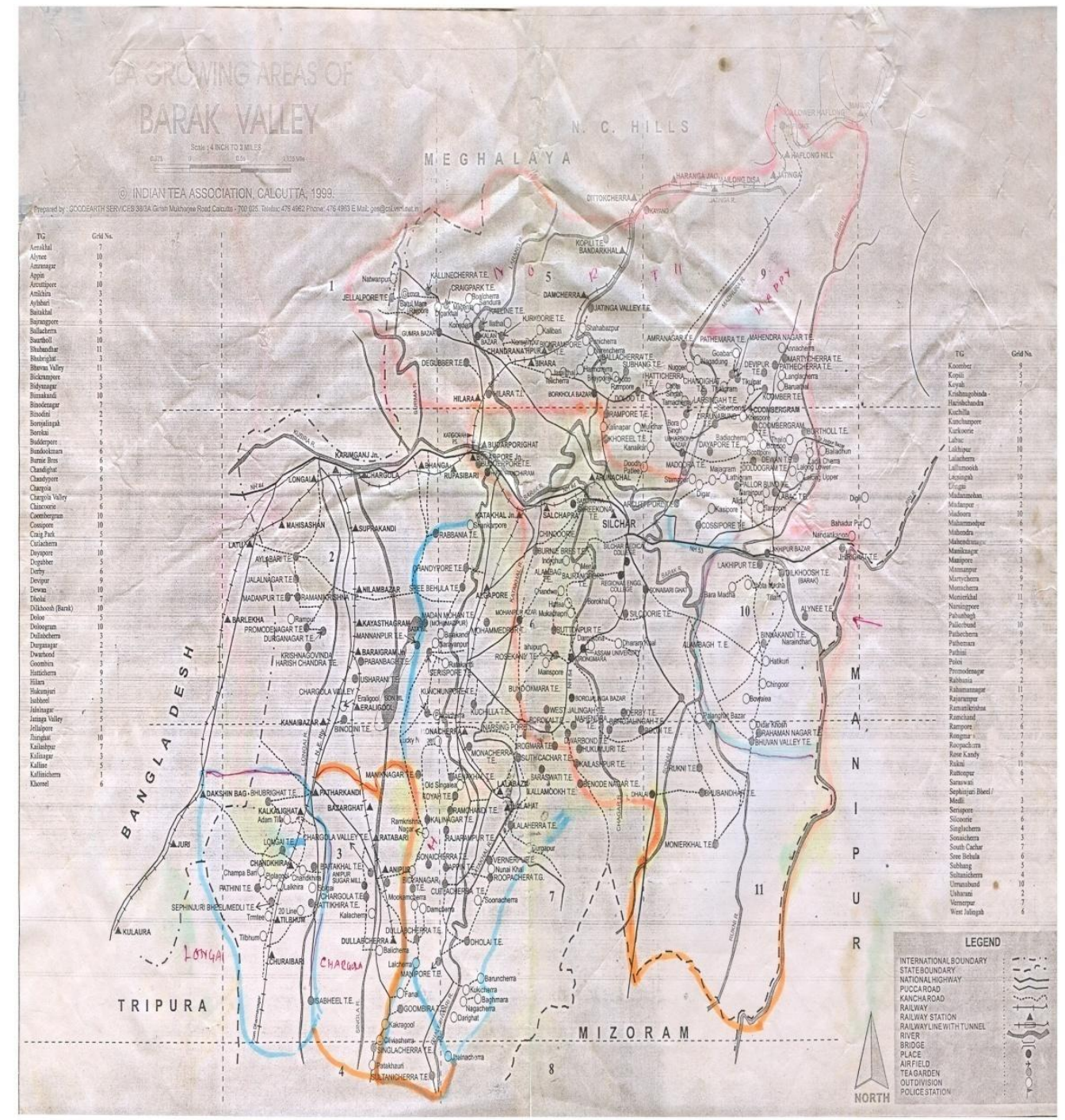

APPENDIX

TEAGROWING AREASOF BARAKVALLEY 